\title{
Will enhanced judicial training in environmental law influence the number of infringement cases against Member States?
}

\section{Ingrida Ilgauskiené $\dot{\mathbf{1}}^{1}$}

Published online: 16 June 2017

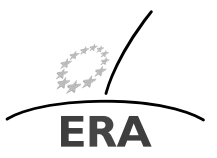

EUROPÄISCHE RECHTSAKADEMIE ACADEMY OF EUROPEAN LAW ACADEMIE DE DROIT EUROPEEN ACCADEMIA DI DIRITTO EUROPEO

(C) ERA 2017

TRIER - TREVES - TREVIRI

\section{Introduction}

The need for continuous judicial training in how to correctly apply and implement the entire body of the EU environmental acquis has been repeatedly evoked both at the European Union (hereinafter EU) level as well as at national level. The EU is built on law, combining Union law with that of the 28 different national legal systems, with both being applied by national judges. ${ }^{1}$ Training of legal practitioners in EU law "helps ensure the coherent application of EU law everywhere in the EU, ensure mutual trust in cross-border judicial proceedings, and spread knowledge of good practices to joint problems in the judicial world", as noted by Věra Jourová, Commissioner for Justice, Consumers and Gender Equality. ${ }^{2}$

There has been a number of communications ${ }^{3}$ from the Commission addressing the ambitious objectives set by the 2010 Stockholm Programme of increasing the

\footnotetext{
${ }^{1}$ European Commission (2011), Communication from the Commission to the European Parliament, the Council, the European Economic and Social Committee of the Regions on "Building trust in EU-wide justice: A new dimension to European judicial training”, COM(2011) 551 final, Brussels, 13.09.2011, p. 2.

${ }^{2}$ European Commission (2016), Report on European judicial training 2016, p. 1.

${ }^{3}$ European Commission (2007), Communication from the Commission on A Europe of results-applying community law, COM(2007) 502 final, Brussels, 05.09.2007; European Commission (2008), Communication from the Commission to the European Parliament, the Council, the European Economic and Social Committee and the Committee of the Regions on implementing European Community Environmental
}

$\varangle$ Dr I. Ilgauskienè, Course Director (Lawyer) in Environmental Law

IIlgauskiene@era.int

1 Public Law Section, ERA, Trier, Germany 
number of European judicial training activities and their quality in partnership with the Member States, judicial training providers and the legal professions themselves at local, national and European level. Priority is given to national judges and prosecutors as they are the ones who enforce EU law. It is no less essential for other legal practitioners as well. ${ }^{4}$ The set target of training at least $5 \%$ of legal practitioners in EU law every year ${ }^{5}$ has already been exceeded, as it has been estimated that in 2015 more than 124,000 legal practitioners received training on EU law or on the national law of another Member State. ${ }^{6}$

\section{Infringement procedures in the area of environmental law}

The Commission states that the enforcement of EU law must be ensured by effective and timely implementation at national level. ${ }^{7}$ Statistics of known infringement procedures against Member States in the environment area show significant shortcomings in the implementation and enforcement of EU environmental legislation. ${ }^{8}$ The environment is thus one of the main policy areas in which most EU pilot files were opened in 2015 (101 cases), and is the policy area having the largest number of uncompleted cases at the end of 2015 (298 open files). ${ }^{9}$ Similar statistics could also be provided for infringement procedures-126 new infringement cases were opened against Member States at the end of 2015, with 276 open cases in total accumulating in the environmental area, constituting over 20 percent of all infringement cases at the end of 2015. ${ }^{10} 88$ new late-transposition infringement cases were opened in the environmental policy area in $2015 .^{11}$

The data provided in the Annual Report on the monitoring and application of EU law show that all Member States have been accused of insufficient or delayed transposition of EU legislation. No statistics are provided on the number of accused Member States in the area of environmental policy. The analysed data however suggest that the role of legal practitioners, especially judges and prosecutors, in upholding environmental law is crucial. At the same time it may also signal either insufficiencies in judicial training in EU environmental law or the complexity of the topic, which needs to be reassessed in order to ensure efficient judicial training in this area of policy.

Law, COM(2008) 773 final, Brussels, 18.11.2008; European Commission (2011), Communication from the Commission to the European Parliament, the Council, the European Economic and Social Committee of the Regions on "Building trust in EU-wide justice: A new dimension to European judicial training", COM(2011) 551 final, Brussels, 13.09.2011; fn. 1.

${ }^{4}$ Supra fn. 3, COM(2007) 502 final, p. 4.

${ }^{5}$ Supra fn. 1, COM (2011) 551 final.

${ }^{6}$ Supra fn. 2, p. 2-3.

${ }^{7}$ Supra fn. 3, $\operatorname{COM}(2007) 502$ final.

${ }^{8}$ European Commission (2016), Report from the Commission, Monitoring the application of European Union law: 2015 Annual Report, COM(2016) 463 final, Brussels, 15.07.2016.

${ }^{9}$ Supra fn. 8, p. 20-21.

${ }^{10}$ Supra fn. 8, p. 23-25.

${ }^{11}$ Supra fn. 8, p. 29. 


\section{Judicial training on environmental law}

In 2012, the European Commission awarded ERA for the first time a Framework Contract "Co-operation with national judges in the field of environmental law" for the period 2012-2016. The programme was designed in close cooperation with individual judges, national judicial training centres, and judges' professional associations (the Association of European Administrative Judges and the EU Forum of Judges for the Environment), who are represented in the programme's Steering Committee.

The aim of the programme is to develop training materials on various sectors of EU environment policies and legal instruments, enrich the already existing material with new elements, extending its scope and enhancing the partnership with national judicial training centres with a view to ensure that the results of this project are multiplied at national level.

The Contract activities will be completed after the implementation of a series of workshops on EU Water Law in May 2017. Besides the production of an impressive number of training modules and e-learning tools as set out below, 495 national judges and prosecutors from 26 Member States have been trained on these so far. In January 2017, ERA was awarded a new Framework Contract for the implementation of the third phase of the programme (2017-2020), which foresees the development of various new modules as well as the revision and/or update of the existing ones.

\subsection{Needs assessment in the field of environmental law}

The main aim of cross-border training under the auspices of the Framework Contract devoted to national judges and prosecutors in the field of environmental law "from different legal, linguistic and cultural backgrounds is to acquire capabilities, skills and knowledge in a high-quality training setting through interactive tailor-made training formats". ${ }^{12}$ Even though the need for such forms of training is rather high and no-one denies their importance both for the EU and for national judges, there are a number of persisting deficiencies in their coherent and effective application across the EU, especially:

- The objective training need in EU environmental law for judges or prosecutors is not always obvious. Most jurisdictions deal with a limited number of environmental law cases only, and when doing so do not necessarily realise that they are applying EU environmental law due to the fact that it has been enacted in the form of directives which, when implemented by national legislation, make it difficult for national judges to recognise their EU law origins. When a judge is called upon to rule in a case, s/he mainly deals with national administrative law. This difficulty might be overcome by integrating the national law perspective into the training module concept.

- The objective training need in EU environmental law for judges and/or prosecutors is essentially occasional. A factor to be faced at European level is the lack of specialisation of most competent courts or judges in the field of environmental law.

${ }^{12}$ EJTN Handbook on Judicial Training Methodology in Europe, prepared with the support of the European Union, January 2016. 
This means that an individual judge is rarely confronted with an environmental case. This problem cannot be overcome at the level of general training-a special tailor-made training concept suitable for these judges needs to be developed, preferably at national level.

- Language barriers may be another impediment in access to European training tools, as most of the prepared online (as well as face-to-face) training modules are only available in English.

- Not all areas of the EU environmental law are already covered by existing elearning modules. On the other hand, the exclusive focus on the EU legal framework in the developed e-learning modules risks to limit their re-use at national level, as law enacted in the form of directives may take a considerably different shape as part of the legal order and vary from jurisdiction to jurisdiction.

\subsection{Conceiving the training programme}

With its environmental law training programme, ERA targets the judiciary of all EU Member States. It is quite challenging to offer a training programme suiting the diversity of all the judiciaries, especially having in mind the increasing workload of national judges and prosecutors, frequent legislative reforms both at national and EU level, and the growing complexity of judicial procedures due to technical possibilities.

The first concept for the training module is further developed in a threedimensioned analysis, meaning that a legal expert in the specific area of law (for a content-related analysis), a practicing judge or judicial trainer (to analyse its practical applicability) and an expert in methodology and adult training (to analyse the suggested format of the training) discuss the chosen topic(s) and structure the training programme with possible subtopics and training formats to be covered during the event. This analysis allows to identify the most relevant topics for (almost) all judiciaries of EU Member States at the time, and also to structure the programme in a way ensuring it is effectively transferred to national jurisdictions. ${ }^{13}$

\subsection{Judicial trainers}

Various competencies are required to implement training for the judiciary. It can be quite challenging to find a trainer who has in-depth knowledge of the topic, a sound understanding of the tasks of the training participants and good communication as well as andragogy skills. Furthermore, there are rather few legal practitioners/trainers specialising in environmental law both at EU and national level.

In implementing various training modules on environmental law, it was noticed that participants prefer trainers to be judges or legal practitioners able to understand their working perspective and to provide practical guidance and relevant feedback. ${ }^{14}$ Depending on the training topic, it is also useful to involve trainers from other backgrounds (academics with or without a technical background, staff of executive bodies,

\footnotetext{
${ }^{13}$ Supra fn. 12, p. 10.

${ }^{14}$ European judicial training_advice for training providers, DG Justice, European Commission, 2015, p. 4.
} 
customs officers, staff of EU institutions as well as from national authorities and so on) in order to provide a full picture of the topic.

Trainers with in-depth specialist knowledge in any of the environmental law areas, good pedagogical skills and well evaluated by participants and judicial training advisors in previous events, are added to the extensive pool of experts built by ERA and will be contacted for workshops and conferences in the future. Some of these are also involved in judicial training in their country of origin and/or active in professional judges' associations.

\subsection{Face-to-face training methodology}

The programme for face-to-face training on any of the chosen EU environmental law topics is usually structured according to the same principle and the same methodological approach.

The introductory session is devoted to setting the scene of the whole training. First, it is used to introduce the non-legal background of the topic, focusing mainly on the social, economic, political, scientific and possibly health impact on human beings as well as on the environment and why judges and prosecutors should consider both the protection of individual rights and the general good in this area of law.

The second part of the introductory session focuses on a detailed overview and explanation of the main legal instruments at stake, allowing the participants to become familiar with the legal framework, policy issues and case law in the specific area. The aim of the introductory part is achieved if the participants are familiar with the applicable legal framework and aware of the consequences which a breach of EU law in this area may cause.

The second part of the programme usually focuses on the main legal instrument (usually a Framework Directive) regulating the specific area of environmental law. The presentation of the law is followed by one or more fictitious practical case studies, highlighting the key points of the theoretical presentation.

The case study part may be implemented in two ways - either separate case studies are developed for every specific legal instrument in the programme (usually a training module includes four practical case studies) as a kind of follow up or variation on the previous one; or one core case study is constructed by different experts cooperating in its drafting, which is worked on during the whole workshop focusing on different legal issues or separate legal instruments. The advantage of implementing the case study in the latter way is that in each phase of the case study discussion it is possible to refer back to earlier presentations and key messages encountered therein without spending too much time on familiarisation with new facts and a different background description each time.

The third and fourth parts of the training programme focus on other related legal instruments (daughter directives) and are followed by further discussions based on practical cases. Structuring the programme in this way allows covering the main legal instruments in detail, and verifying the theoretical knowledge acquired during the practical case studies in smaller groups.

The training programme ends on a more horizontal topic-discussing the role of a national judge in the implementation of a specific legal instrument at national level. 


\subsection{The training modules: blending e-learning and face-to-face training}

The training modules under this specific Framework Contract are usually implemented in three interconnected blocks: blended e-learning, face-to-face presentations and practical case studies.

Blended e-learning training tools allow users to acquire the necessary level of practical skills and understanding at their own pace. A further advantage of the blended learning approach is that it allows for a greater depth of knowledge to be conveyed over a longer period, having full access to the content before, during and after the face-to-face workshop which is part of the programme, as well as using it as a point of reference for information on the specific subject. It allows for content to be studied in advance, thereby facilitating better informed discussions and enabling participants to exchange opinions and practices on a well-founded basis.

Hence a main function of the e-learning content is the introduction of end-users to the area of law covered by the training module. In order to achieve this, the course includes a general overview of the area covered by the specific training module. The main EU law provisions covered in the training are presented, as well as their position in the general legal framework and how they relate to other international, EU or national legal instruments. The most significant case law of the CJEU is also integrated to equip users with the necessary tools for interpreting the different instruments.

A quiz, provided at the end of the blended e-learning material, offers users the possibility to assess their knowledge in the area of law covered, allowing them to check their progress by comparing their results before and after the course, and to identify areas where they still encounter difficulties.

Subsequent face-to-face training allows to go into depth with the topic. It also offers participants to ask questions and raise issues of their own experience. Depending on the content of the presentation(s), participants are encouraged to ask questions in the course of the presentation or in the subsequent discussion. To increase interaction at this stage, the trainer includes short case studies and/or examples in his/her presentation, animating participants' reflection and active involvement.

Before the workshop, the participants usually receive a participant's pack including a list of background material with hyperlinks to original sources, other databases, sources, networks and websites for international agreements, EU legal acts, policy documents, communications and reports, case law of the CJEU and other related materials. These will be integrated in the course where and when suitable according to the selected learning flow.

\subsection{Evaluation of the training}

ERA usually conducts a two-stage evaluation of the trainings in order to ensure that the materials, structure and training methodology meet the objective and are constantly improved. Participants are usually asked to provide their feedback in two ways:

- at the very end of the workshop, providing immediate feedback on the speakers, topics, methodology and overall implementation of the training; 
- in a completed detailed evaluation form on the assessment of the organisation and comments on speakers, giving their opinion on expert knowledge, contents of lectures, lecturing style, presentation and the discussion of each lecture; assessing the value of the case studies and providing suggestions for further improvements as well as insights on whether they received useful advice on application and implementation.

The evaluation of the training is also carried out with the trainers and the judicial training advisor. All feedback received is shared with the trainers in order to adjust the developed training materials accordingly and to make the training module ever more user-friendly and effective.

\subsection{Training materials developed since 2012}

Since late 2012, training modules_including blended e-learning and stand-alone courses-designed by ERA have covered:

- Air Quality and Noise Legislation

- Biodiversity and Wildlife Trafficking

- Participatory and Procedural Rights in Environmental Matters

- Industrial Emissions

- EIA and Nature Directives

- EU Waste Law

- EU Water Law.

All the information in relation to this project and the above training materials is available on the ERA website and is freely accessible to all interested parties at: www.era.int/judges\&environmental_law

Since the "Cooperation with national judges in the field of environmental law" Programme was launched in 2008, other training modules were also developed in the first four years. They are all available on the European Commission's DG ENV website: http://ec.europa.eu/environment/legal/law/training_package.htm. ${ }^{15}$

\section{Conclusion}

In summary, the need for judicial training in environmental law is of the greatest importance. The response to that is an offer of high-quality training. ERA has been developing a wide variety of training modules to cater for this demand and aims to offer more tailor-made high quality trainings in the future, both to the judiciary in the framework of the new Contract and to legal practitioners in the framework of its general programme. It is very much hoped that this will provide an effective tool to assure a better application and enforcement of EU environmental law in the Member States and reduce the number of infringement proceedings to a minimum level.

\footnotetext{
${ }^{15}$ Between 2008 and 2012, training modules were developed on the following topics: EU Law on Environmental Impact Assessment (EIA), EU Law on Nature Protection, EU Waste Legislation, EU Water Legislation, Principles of EU Environmental Law, and Protection of Environment through Criminal Law. Training materials were also made available on: Access to Justice in Environmental Matters, as well as The Role of National Courts and the EU Commission as concerns the implementation of European environmental legislation.
} 